\title{
Schistosomiasis Mansoni in Bananal (State of São Paulo, Brazil). IV. Study on the Public Awareness of its Risks in the Palha District
}

\author{
Rubens Antonio da Silva ${ }^{+}$, Maria Esther de Carvalho, Fabiana Zacharias, \\ Valquíria R de Lima*, Horacio MS Teles*
}

Laboratório de Soroepidemiologia *Laboratório de Malacologia, Coordenação dos Laboratórios de Referência e Desenvolvimento Científico, Superintendência de Controle de Endemias, Rua Paula Souza 166, 01027-000 São Paulo, SP, Brasil

A rather high prevalence of mansoni schistosomiasis has been observed in some localities of Bananal, State of São Paulo, during the past decade. The highest prevalence of schistosomiasis was found in the Palha District; it was thus considered adequate for an evaluation of public awareness of the risks involved in acquiring schistosomiasis, a likely outcome of certain behavior patterns. We interviewed 542 district-dwellers. The 5-to-39 age-group constituted $65.5 \%$ of the whole sample. Concerning the infection, $69.2 \%$ had hearsay information; $46.1 \%$ know the infection; $69.6 \%$ know how it is acquired; $31.5 \%$ know about the symptoms and $57.1 \%$ know what can be done to avoid infection; $17.7 \%$ declared to have acquired the infection at least once in their lifetime; $62.3 \%$ reported total or partial immersion in collections of water of Bananal, once or twice a week, 53.9\% of these for bathing or fishing. Although most (91.7\%) households have treated running water, are connected to the sewage network or have septic tanks, $9 \%$ of the people interviewed use to defecate on the field.

It became clear that the educational messages aimed at this population had not been adequate, having failed to fulfil any expectations. The local people received only piecemeal and subjective information about their problem. The control of schistosomiasis requires an integrated practice, which includes the analysis of macro-determinant factors, such as basic sanitation, habitation, education and health care. In short, we require a multidisciplinary vision of the mechanisms of transmission of the infection, which depends upon adequate planning and well trained personnel, intent on their educational work, to attain satisfactory results.

Key words: schistosomiasis - risk evaluation - health education - São Paulo - Brazil

Since it was first diagnosed in Brazil, schistosomiasis has expanded over large areas due to massive and frequent migration of infected people into locals where poor sanitation prevails (Passos et al. 1998). The first measures to control schistosomiasis were implemented in the 5 th decade of the 20th century. Only on a few occasions the local residents took any part in the works, as demonstrated by Barbosa et al. (1971), Barreto \& Prata (1969) and Coura-Filho et al. (1992). A holistic approach to the problem of individuals, taking into account their symboliccultural universe, their historical instruction, their weltanschauung and their attitude towards health/disease situations was suggested by Barbosa and Coimbra Jr (1992), Barbosa et al. (1993), Tognoni (1993) and Valla et al. (1993) to implement a practical approach aiming at reducing the local process of disease production. According to this line of argument, from the 1980's to the present time Acioli and Carvalho (1998) observed a dominance of proposals for community participation in programs aimed at controlling endemic diseases.

In spite of the fact that communal participation and mobilization in the fight against endemic diseases is very significant indeed, the task of putting this plan into prac-

$\overline{{ }^{+} \text {Corresponding author. Fax }}$ +55-11-229.8292. E-mail: rubens@sucen.sp.gov.br

Receive 18 June 2002

Accepted 15 August 2002 tice proved to be more difficult than we had expected. For the organization and execution of actions, no models are available to help organizing and executing control and vigilance against the spread of endemic diseases, among which Schistosoma mansoni infections. In the specific case of this endemic disease, the prophylactic measures prescribed by control programs are the search for and treatment of human carriers, the use of moluscicides, improvement of basic sanitation facilities and, last but not least, health education, understood as a strategy to make the people more conscious about the proper use of bathroom appliances and to collaborate in programming further prophylactic measures intended specifically to control the transmission of schistosomiasis, as emphasized by Alves et al. (1998).

The control of schistosomiasis is one of the most difficult public health tasks, by reason of the distribution of vector snails over large areas of many states of Brazil, the numerous human activities related to agricultural or domestic work, or leisure, the dynamic characteristics of different foci, lack of potable water and restrictions on individual and mass treatment, in addition to a generalized lack of adequade organization of preventive and curative medical services (Coura-Filho 1998).

While discussing the measures taken to interfere with the mechanisms of $S$. mansoni transmission, some authors remarked that the most important measures to be introduced for general use in control programs are: health education and basic sanitation, viz adequate sewage disposal and water treatment in addition to vector snail control. These authors emphasize the fact that such measures are 
far more effective when one takes into account the participation of the local population than expected when they are evaluated separately (Barbosa 1995, Coura 1995, Dias et al. 1995).

The Superintendência de Controle de Endemias Sucen (Superintendency for the Control of Endemic Diseases), an autarchic state-owned enterprise linked to the Health Secretariat of the State of São Paulo, is currently investigating action and messages aiming at having a better access to the public and spurring them to participate in the actions of society, which include environmental and epidemiological information in connection with parasitic vectors. This involves an analysis of social and cultural factors pertinent to the prevention and control of the infection, which will contribute to adaptation of educational activities in an effort to motivate an increasing percentage of the population to adopt preventive measures. A pilot study was initiated in the Palha District, Bananal, as a contribution to the implementation of improved health education projects aimed at controlling the transmission of schistosomiasis in the State of São Paulo.

\section{MATERIALS AND METHODS}

The municipality of Bananal, $615 \mathrm{~km}^{2}$ in area, at an altitude of $560 \mathrm{~m}$, lies in the southeastern part of the State of São Paulo (22 40 '44”'S, 4419'08'W), 346 km distant from São Paulo by highway. It belongs to the Administrative Region of São José dos Campos, DIR XXIV, Taubaté. Its climate is tropical, with quite mild temperatures all over the year. Of a population of 9,713 (IBGE 2000), about $73.9 \%$ live in the urban and $26.1 \%$ in the rural area.

This study was conducted during July 2001, in the Palha District, selected for the persistence of high prevalences of the infection, even after the strengthening of the control action. We worked out a questionnaire, which had been previously tested and adjusted to a sample of 542 individuals from this district, covering $80.9 \%$ of a population of 670. It was intended to evaluate the degree of public awareness of the risks of schistosomiasis. Personal data, such as sex, age, period of residence in the district, and education were also collected. Data about awareness and attitudes to the problem were collected by using multiple-choice questions. The information collected was processed by using the computer programs Epi-Info 6.0 (Dean et al. 1994) and Fox-Pro ${ }^{\circledR}$ for Windows. As this investigation involved human beings, a written consent for filling in the questionnaire was obtained from the subjects, according to the ethical rules of the Helsinki Declaration.

\section{RESULTS}

There were $305(56.3 \%)$ residents of the female sex, a significantly higher proportion $(\mathrm{P}<0.01)$. Most of the residents (418 or $77.3 \%$ ) were in the 1 to 39 years age group (Table I). According to occupation, the female residents were so distributed: 79 (25.9\%) housewives, 63 (20.7\%) students, 55 (18\%) housemaids. Male residents: $42(17.7 \%)$ students, $37.9(16 \%)$ jacks of all trades and 26 (11\%) bricklayers. As to schooling, 405 (74.7\%) residents can read and write and 297 (54.8\%) are attending first school. As a measure of the public awareness of schisto-
TABLE I

Distribution, according to sex and age group, of the population interviewed in the Palha District, municipality of Bananal, State of São Paulo, Brazil, 2001

\begin{tabular}{|c|c|c|c|c|c|c|}
\hline \multirow{2}{*}{$\begin{array}{l}\text { Age group } \\
\text { Years }\end{array}$} & \multicolumn{2}{|c|}{ Female } & \multicolumn{2}{|c|}{ Male } & \multicolumn{2}{|c|}{ Total } \\
\hline & No. & $\%$ & No. & $\%$ & No. & $\%$ \\
\hline$<1$ & 3 & 0.5 & 5 & 0.9 & 8 & 1.5 \\
\hline $1-4$ & 28 & 5.3 & 36 & 6.6 & 64 & 11.8 \\
\hline $5-9$ & 28 & 5.3 & 32 & 5.9 & 60 & 11.1 \\
\hline $10-14$ & 49 & 9.0 & 32 & 5.9 & 81 & 14.9 \\
\hline $15-19$ & 26 & 4.8 & 24 & 4.4 & 50 & 9.2 \\
\hline $20-29$ & 59 & 10.9 & 35 & 6.5 & 94 & 17.4 \\
\hline $30-39$ & 42 & 7.7 & 28 & 5.3 & 70 & 12.9 \\
\hline $40-49$ & 30 & 5.5 & 18 & 3.3 & 48 & 8.8 \\
\hline $50-59$ & 18 & 3.3 & 10 & 1.8 & 28 & 5.2 \\
\hline $60-69$ & 12 & 2.2 & 7 & 1.3 & 19 & 3.5 \\
\hline$\geq 70$ & 10 & 1.8 & 10 & 1.8 & 20 & 3.7 \\
\hline Total & 305 & 56.3 & 237 & 43.7 & 542 & 100 \\
\hline
\end{tabular}

somiasis, we found that $375(69.3 \%)$ of the subjects answered yes to the question whether they had heard anything about schistosomiasis, $173(46.1 \%)$ having declared to know what kind of disease it is (Table II).

Questions on "How does a person catch this disease?" "What a person with this disease feels?" "What can be done to avoid catching this disease?" were answered, respectively, by 261 (69.6\%), 118 (31.5\%) and $214(57.1 \%)$ subjects. During the interview they were asked to illustrate their statements with examples. The number of correct answers was reduced when affirmative answers were compared with the related examples.

Concerning diagnosis, $85.4 \%$ of the subjects interviewed declared to have sent stool samples for examination. This is done in Bananal as an active search, i.e. containers are distributed door-to-door, collected and sent to the laboratory. A positive result for some helminthiasis was reported by $31.4 \%$ of those who had sent stool samples. It should be explained that the identification of protozoa is not possible when the "Kato-Katz" technique is used, as it is the case. Table III summarizes the data about subjects who declared to have been infected at least once. The mean period of time for acquiring the infection was two years for one infection only. On the average, the first infection ocurred at the age of 18.0 years. Of the subjects who reported positive results, $36 \%$ declared to be asymptomatic and $10.5 \%$ were not treated.

Water contact once or twice a week was reported by 340 of the residents interviewed. Bathing and fishing accounted for $53.9 \%$ of all water contacts. Although most of the households have treated running water and adequate sewage disposal, $9 \%$ of the people interviewed relieve themselves in the open.

Knowledge about the action taken against schistosomiasis was declared by $183(33.8 \%)$ of the residents. It is worth mentioning that $61.6 \%$ of the residents declared that they had never received any information about the disease (Table IV). 
TABLE II

Public awareness of the transmission mechanism of schistosomiasis, Palha District, municpality of Bananal, State of São Paulo, Brazil, 2001

\begin{tabular}{|c|c|c|c|c|c|c|c|c|}
\hline \multirow[b]{2}{*}{ Question } & \multicolumn{2}{|c|}{ Yes } & \multicolumn{2}{|c|}{ No } & \multicolumn{2}{|c|}{ Could not answer } & \multicolumn{2}{|c|}{ Total } \\
\hline & No. & $\%$ & No. & $\%$ & No. & $\%$ & No. & $\%$ \\
\hline Have you heard about schistosomiasis? & 375 & 69.2 & 64 & 11.8 & 103 & 19.0 & 542 & 100 \\
\hline Do you know what is schistosomiasis? & 173 & 46.1 & 201 & 53.6 & 1 & 0.3 & 375 & 100 \\
\hline How do you catch schistosomiasis? & 261 & 69.6 & 105 & 28 & 9 & 2.4 & 375 & 100 \\
\hline What do you feel when you catch schistosomiasis? & 118 & 31.5 & 241 & 64.3 & 16 & 4.3 & 375 & 100 \\
\hline What can you do to avoid catching schistosomiasis? & 214 & 57.1 & 143 & 38.1 & 18 & 4.8 & 375 & 100 \\
\hline
\end{tabular}

TABLE III

People who are aware of having already catched schistosomiasis, Palha District, municipality of Bananal, State of São Paulo, Brazil, 2001

\begin{tabular}{ll}
\hline Variable $\mathrm{n}=96$ & Value \\
\hline How long? & Average 2 years \\
How many times? & Average 1 \\
Most mentioned symptoms & No symptom $36 \%$ \\
& Dizziness $12.8 \%$ \\
& Abdominal pain $10.4 \%$ \\
Always treated? & Yes $89.5 \%$ \\
\hline
\end{tabular}

\section{TABLE IV}

Sources of information about schistosomiasis mentioned by the inhabitants of Palha District, municipality of Bananal, State of São Paulo, Brasil, 2001

\begin{tabular}{lrr}
\hline Where did you get information from & No. $^{a}$ & $\%$ \\
\hline Sucen & 93 & 15.8 \\
Health Care Unit & 73 & 12.3 \\
School & 32 & 5.4 \\
Family & 21 & 3.7 \\
Other & 07 & 1.2 \\
Never got information & 363 & 6.6 \\
\hline Total & 589 & 100 \\
\hline
\end{tabular}

$a$ : multiple answers

\section{DISCUSSION}

The municipality of Bananal is part of a region of the valley of River Paraíba do Sul where schistosomiasis mansoni is endemic. It is considered as the most important focus of the State of São Paulo (Silva 1983).

To get the active participation of most local people in disease control programs presupposes that individuals are the main object of interest. Their knowledge about cause, prevention and treatment of the infection, the importance of water contacts and socio-economical factors define a specific mode of transmission for distinct strata of individuals (Coura-Filho 1998). The importance of public schooling can not be denied: the better, the easier assimilation of new facts and concepts and practical attitudes compatible with the prophylaxis of an infection such as schistosomosis. The fact that $53.9 \%$ of a population sample declared not to know about the disease demonstrates a communication gap, so that its target, which is prevention of the endemic disease has not been reached (Table II). A similar situation has been described by Alves et al. (1998). The relation between "knowing something about the disease" and "being able to describe correct instances" demonstrates that only fragmentary concepts of the subject were assimilated by the locals, composed of a mixture of scientific information, cultural and subjective components.

Professionals dealing with educational problems aim at defining their targets according to a comprehensive health education philosophy. Under the circumstances, some difficulty, on the part of the public, in decoding messages and general information coming from public health personnel was observed. As an alternative to this situation, Coura-Filho (1996) suggests a standardization of information to be the subject-matter of special courses, which should include the integral participation of all personnel, aiming at improving one's achievements as a citizen. Using a model set forth by Barbosa et al. (1993) in the municipality of Afonso Cláudio, State of Espírito Santo, Brazil, a joint control program was implemented with the local Health Care Office and an active participation of the community. During this study, mass specific treatment and the use of moluscicides were excluded from the program. It was expected that the model would reduce the indicators of the endemicity in this region and that partaken research would be the starting point for the process of data collection and analysis. Active participation of the population in the action of control is a collective mobilization towards public health activities (Barbosa 1995).

Kloetzel (1992) states that the control of schistosomiasis with modest investments is possible, as attest the results attained in Taquaraçu, State of Minas Gerais, Brazil. Selective chemotherapy and basic sanitation plus a minimum of sanitary education, plus a mobilization of the community, could succeed although in the long term, in controlling schistosomiasis.

According to Barbosa (1995) and Coura-Filho (1998) a model for the control of schistosomiasis, or for that matter, any other endemic disease should be based upon a socio-cultural paradigm which could explain the various processes of endemic disease production, as individuals cannot be held responsible for the production of their own diseases.

An important aspect of this subject, which must be taken into consideration when evaluating programs intended for the control and fight against schistosomiasis, concerns the process by which people are "conducted" to thinking and concerning themselves with the different occasions in which the requirements for the initiation of a 
focus of the parasite, and eventually the diffusion of an infection, are fulfilled. Any program can be a total or partial failure, should due consideration and understanding of such problems not be given. In the case that a segment of $38.3 \%$ of the population interviewed is composed of students, one can only think that the school should be held responsible for the poor achievement of its pupils: it is the source of only $4.5 \%$ of the total information received. One objective of schooling is to contribute to the pupil's understanding and identifying instances of attitude and practice which can be harmful to individual or collective health. They should be able to participate in groups, look for solutions to their problems, adapt their behavior to new situations, modifying those which can be the cause of diseases (Alves et al. 1998).

A point which must be emphasized is that a piece of information gathered from the subjects of the investigation was the permanence of such usage as not using toilets. Obviously, S. mansoni transmission depends upon environmental contamination, a determinant of the formation of foci, which is independent from basic sanitation (Silva 1983). Given the vector snails and a frequent contact of people with the contaminated water, another focus is in action.

Coura-Filho (1998) emphasizes the existence of a close association of economical environmental and behavioral conditions and the transmission of schistosomiasis. More than 50\% of the population of the the Palha District informed to have accasional occupation or underemployment, a situation which is almost always a determinant of substandard socio-economic conditions and considerable barrier to schooling. Acioli and Carvalho (1998) made it clear that critical social, economic, housing and sanitary leads to frequent contacts with the river to provide them with some essential items, as a survival strategy. The dwellers of the Palha District allege that their very frequent contacts with bodies of water in Bananal are a part of their leisure activities.

The fact is that besides the improvement of schooling and resultant active participation in control programs, the fight against schistosomiasis or any other endemic disease requires setting into motion and supervising very complex mechanisms and resources if any result is to be expected. In spite of such complexity, we now have access to methodological and technical short cuts which, as expected, require competent operators, having the ability to solve technical problems and to become integrated with his team and members of the community. Such integration is the key to an efficient public health campaign.

\section{ACKNOWLEDGEMENTS}

To the community health agents of the municipality of Bananal, and, in particular, to Luís Maurício Coutinho and Maria Inês da S Santos, for their dedication with which they offered their cooperation during our activities in Bananal.

\section{REFERENCES}

Acioli MD, Carvalho EF 1998. Discursos e práticas referentes ao processo de participação comunitária nas ações de educação em saúde: as ações de mobilização comunitária do PCDEN/PE. Cad Saúde Públ 14 (Supl. 2): 59-68.

Alves PC, Souza IM, Moura MA 1998. A experiência da esquistossomose e os desafios da mobilização comunitária. Cad Saúde Públ 14 (Supl. 2): 79-90 .

Barbosa CS, Pieri OS, Silva CB, Barbosa FS 2000. Ecoepidemiologia da esquistossomose urbana na ilha de Itamaracá, Estado de Pernambuco. Rev Saúde Públ 34: 337-341.

Barbosa FS 1995. Determination and control of schistosomiasis. Mem Inst Oswaldo Cruz 90: 155-159.

Barbosa FS, Coimbra Jr CEA 1992. Alternative approaches in schistosomiasis control. Mem Inst Oswaldo Cruz 86: 215220.

Barbosa FS, Cruz OJ, Hollanda E, Siqueira SAV, Carvalho MAP, Gomes ML, Almeida AS 1993. Modelo alternativo para o controle da esquistossomose: estado atual do projeto no Estado do Espírito Santo, Brasil. Cad Saúde Públ 9: 85-89.

Barbosa FS, Pinto R, Souza O 1971. Control of schistosomiasis in a small northeast Brazilian community. Trans $R$ Soc Trop Med Hyg 65: 206-213.

Barreto AC, Prata A 1969. Aplicação em massa de moluscicida pela população local em uma área endêmica de esquistossomose. Gaz Med Bahia 69: 20-24.

Borba OF 1981. Aspectos teóricos da pesquisa. In CR Brandão, Repensando a Pesquisa Participante, Brasiliense, São Paulo, p. $42-62$

Coura JR 1995. Control of schistosomiasis in Brazil: perspectives and proposals. Mem Inst Oswaldo Cruz 90: 257-260.

Coura-Filho P 1996. Abordagens alternativas no controle da esquistossomose: buscando incluir o subjetivo na epidemiologia. Cad Saúde Públ 12: 95-101.

Coura-Filho P 1998. Participação popular no controle da esquistossomose através do Sistema Único de Saúde (SUS), em Taquaraçu de Minas (Minas Gerais, Brasil), entre 19851995: construção de um modelo alternativo. Cad Saúde Públ 14 (Supl. 2): 111-122.

Coura-Filho P, Rocha RS, Lima e Costa MFF, Katz N 1992. A municipal level approach to the management of schistosomiasis control in Peri-Peri, MG, Brazil. Rev Inst Med Trop São Paulo 43: 543-548.

Dean AG, Dean JÁ, Coulombier D, Brendel KA, Smith DC, Burton AH, Dicker RC, Sullnam K, Fagan RF, Arner TG 1994. Epi-Info, version 6: a Word processing database and statistics program for epidemiology on microcomputers. Center of Disease Control and Prevention, Atlanta.

Dias LC, Marçal Jr O, Glasser C 1995. Control of schistosomiasis transmission. Mem Inst Oswaldo Cruz 90: 285-288.

Gazzinelli A, Gazzinelli MF, Cadete MM, Filho SP, Sá RI, Kloos H 1998. Sociocultural aspects of schistosomiasis mansoni in an endemic area in Minas Gerais, Brazil. Cad Saúde Públ 14: 841-849.

IBGE-Instituto Brasileiro de Geografia e Estatística 2000. Censo demográfico 2000: resultados preliminares, São Paulo, Brasil, 172 pp.

Kloetzel K 1992. Ciência auto-sustentada: o caso da esquistossomose. Cad Saúde Públ 8: 204-206.

Moza PG, Pieri OS, Barbosa CS, Rey L 1998. Fatores sóciodemográficos e comportamentais relacionados à esquistossomose em uma agrovila da zona canavieira de Pernambuco, Brasil. Cad Saúde Públ 14: 107-116.

Passos ADC 1998. Controle da Esquistossomose: Diretrizes Técnicas, Fundação Nacional de Saúde, Ministério da Saúde, Brasília, 70 pp.

Silva LJ 1983. Sobre a antiguidade de alguns focos de esquistossomose do Estado de São Paulo. Rev Bras Malariol 35: 7378.

Tognoni 1993. Epidemiologia comunitária. Apuntes para una nueva epidemiologia. Salud y Soc 10: 4-10.

Valla VV, Carneiro C, Assis M 1993. Participação Popular e os Serviços de Saúde: O Controle Social como Exercício de Cidadania, Fiocruz, Rio de Janeiro. 